\title{
THE ROOTS OF HUMAN RIGHTS: THE EPISTEMOLOGICAL TURN PROVOKED BY FRANCISCO DE VITÓRIA
}

Claudio Brandão ${ }^{1}$

\section{Abstract}

The late Spanish scholastic had proposed a great turn in knowledge. The head of this school, Francisco de Vitoria, broken the medieval speculative thought and replaced it. By the humanist lenses, a practical thought was developed for solving problems arising from the great navigations, namely, the rights of man in lower civilizations standards. In this panorama, Vitoria proposed the concept of potentiae rationales and many others, which had extraordinary importance to the subsequent German's natural law school. Thus, Vitoria is in the roots of the concept of Human rights.

\section{Keywords}

Francisco de Vitória. Humanism. Rational potency. Rationality. Human rights.

\section{Summary}

1. Distinctiveness of Vitoria's thought. 2. The normative standards and rationality: the nature of norm. 3. The meaning of Human rights in late Spanish scholastics. 4. Final note. References.

${ }^{1}$ Full Professor of Criminal Law and Legal History. Damas Catholic College, Catholic University of Minas Gerais and State University of Pernambuco. Brazil. 


\section{DISTINCTIVENESS OF VITORIA'S THOUGHT}

Francisco de Vitória is the founder of the Salamanca's school of natural law, which has a special characteristic, namely, the application of jus gentium in perspective of the relationship between nations.

The work of Vitoria has broken paradigms. Before him, the knowledge produced by the Salamanca's scholars was based in Petrus Lombardus' Libri quatuor sententiarum, according the official statue of the University. Lombardus' sententiae was guided by speculative thought, that basically distinguishes the city of God and the city of Man, looking for the spiritual concepts as its main object. For his propose, the author had reunited texts of the Bible and phrases of the Patristic authors and theologists (sententiae). From the Medieval times, the two pillars of education were Lombardus and Gratian, and theology and canon law where appointed as "twins brothers".

In the sixteenth century, Vitoria was the head of the most important chair in Salamanca University ${ }^{3}$ - the cathedra prima - and, with no statute's

2 "Medieval intellectuals knew also Gratian and the Lombard as eminent teachers through the textbooks which they had written and which were used in the basic teaching of canon law and theology throughout the middle ages and beyond (...) The pairing of Gratian and the Lombard is in fact common both in modern scholarly literature and in medieval writings. One of the more fanciful examples is the widespread medieval story that they were brothers, or even twins. Credence is not given to this myth, and with good reason, but the pairing itself recognizes an important fact. Gratian and the Lombard were not twin brothers, but the twin pillars on which medieval education in theoretical and practical theology built. They had, each in his discipline, produced the first successful compendium, comprehensively summarizing the learning of that discipline using the scholastic methods that were newly fashionable in their time, the middle of the twelfth century." WINROTH 2000, 1-2.

3 "In 1526, Vitoria ascended to the position of Prime Chair of Theology of the University of Salamanca and definitively established himself in the Monastery of San Esteban of 


\section{Claudio Brandão ITHE ROOTS OF HUMAN RIGHTS I ISSN 2675-1038}

changes, he began to teach Thomas Aquino's theology instead of Lombardus' sententiae. And did more, actually he thought about the application of both Aquino's theology and humanism to the era of the great navigations and conquers.

The first labor of Vitoria, in the first decades of the $16^{\text {th }}$ century, was devoted to comment the theology produced by Thomas Aquinas and, also, by the humanism from the Parisian school ${ }^{4}$. But the most important part of his work was devoted to solve the problems arising from the conquest and colonization of America, as we can study in De Indis. This means that Vitoria made a great epistemological turn: the speculative thought drops its importance and was replaced for the practical thought ${ }^{5}$.

The practical thought proposed by Vitoria represents the meeting of the classical culture despised by the medieval thought. In true, this was developed by the humanism, that grew up at Paris University, where

Salamanca. In his intellectual prime, and with an excellent background, he was able to discern and appreciate the difficulties and disquiet of his time with a lucidity that surprised his contemporaries. He soon found many good friends and admirers among the humanist community in Salamanca, including Herna'n Nfifiez de Guzmfin, professor of Greek, Juan Martinez Siliceo, professor of natural philosophy, Bernardino Vaizquez de Oropesa, professor of Biblical studies, and the theologian Martin de Frias." HERNÁNDEZ 1991, 1037.

4 "Nearly the entire sixteenth century pacifist movement proceeded from humanism, which took effect on the Spanish thinker while his church ministry thriven, ever since earlier times. In 1520, during his stay in Paris, Francisco (de Vitória) established contact with Joost van Assche, Jodocus Badius Ascensius, one of the greatest expressions of humanism". CASELLA 1985, 355.

5 This turn was made by the logical argumentation and by elements of classical culture, thus: "humanists reencountered classical antiquity, and confronted themselves with a system pervaded with the elaborate use of logical argumentation, which, according to the Aristotle's Analytics, distinguished itself as the perfect form of reasoning. Subsequently, this organizing system led to a rationally based search for better comprehending the juridical field and its noteworthy precepts." BRANDÃO 2016, 36. 


\section{Claudio Brandão ITHE ROOTS OF HUMAN RIGHTS I ISSN 2675-1038}

Vitoria had studied. The humanism has stimulated the re-encounter ${ }^{6}$ with the epicureanism, the skepticism and many other schools of the late antiquity put away at medieval times ${ }^{7}$. In details:

"From the early fifteenth century onwards, humanism was born and witnessed its weightiest development. The renewed study of the classical antiquity once despised by the medieval world, enabled the birth of this new field of thought, which emancipated itself from medieval traditions and had especial practical concerns, appraising the human being as the focal point and addressee of knowledge, and setting its sights on the existent problems faced by men. This epistemological emancipation extensively diverged from medieval thinking, whose tradition of speculative contemplation non-rarely dissociated itself from the everyday life, expressing sole attentiveness in metaphysical questions"

This re-encounter made possible the turn for the practical thought and that's the reason humanism has high importance to the late Spanish scholastics, lead by Francisco de Vitória.

In his works, Vitoria has never used the expression Human rights. However, Victoria deals with what is universally equitable for all Human beings, regardless of the development of their civilizing status. And such universal human equity is the conceptual key to solving various practical questions, for example, whether Indians are also subjects of the Emperor and whether they have property rights. In this sense:

6 MEDER 2008, 191.

7 VILLEY 2009, 437.

${ }^{8}$ BRANDÃO 2016, 35. 


\section{Claudio Brandão ITHE ROOTS OF HUMAN RIGHTS I ISSN 2675-1038}

"Francisco de Vitoria is a paradigmatic example of the kind of emergent politics grounded in colonial capitalism. In many senses, Vitoria is frequently considered to be a 'progressive' philosopher of the Conquest. He argued against many of the overtly racist justifications for the Conquest, rejected the claims of Church and Imperial Crown to ownership of the colonies, and defended both the humanity and property rights of the indigenous peoples of the Americas."'

In this panorama, the late Spanish scholastics and specially Francisco de Vitória gave the foundations of the human rights concept.

\section{THE NORMATIVE STANDARDS AND RATIONALITY: THE NATURE OF NORM}

Francisco de Vitoria wrote an explanation about the norm and its rational nature. In effect, his work De legibus pronounce the high importance of rationality and show us the opposition between his thought and the medieval canons, which founded the concept of norm (lex) in God's will. This opposition also "prepared the field" for the basis of Human rights' concept, namely the potentia rationalis.

In his De legibus, Vitoria endorsed a version of Thomas Aquinas's philosophy, recognizing a tripartite nature of the norm: eternal norm, natural norm and human norm. Such revolutionary interpretation was a breakthrough that paved the way for Vitoria's posterior moral reflection on the indigenous people, and on the law of nations. Accordingly, Vitoria's theory of law allowed the theoretical justification of the subjective

${ }^{9}$ BOHRER 2017, 26. 


\section{Claudio Brandão ITHE ROOTS OF HUMAN RIGHTS I ISSN 2675-1038}

conception of norm (rectius, which belongs to every human being), instituted on his comprehension of natural law.

In this view, the essence of the norm (lex) is presented as something that pertains to reason, therefore, since the rule and measure of human activity is reason, its etymology derived from the Latin word ligare (to bind), and it is the function of reason to order to an end, since reason resides in the human intellect. On the subject Vitoria expressed:

"FIRST ARTICLE - Whether norm is something pertaining to reason or resides on reason and will. Responds that norm is something pertaining to reason, because it compels one to act; norm is the rule and measure of human activity, and it is termed law for it proceeds from "ligare", because it binds. It is evident, therefore, that norm is located in the rational nature and, consequently, cannot be founded in other than sensibility or in the intellect. Moreover, it does not reside in sensibility. So..."10

With this assertion, Vitoria refuted the commonly acknowledged notion in the middle Ages that the norm derived from divine will, and therefore it was a consequential product of will. He understood the norm as a mandate, and as such, it is determined by reason and ordered to a finality, which could only be devised from rational activity. Since it is imperative and it is ordered to a goal, the norm shall always be systematized to the preservation of the common good $^{11}$. Likewise, it is relevant to note that

10 Translation of: "ARTICULOS PRIMUS - Utrum lex sit aliquid rationis vel in ratione an in voluntate. Respondet quod lex est aliquid pertinens ad rationen quia ad rationem pertinet imperare; et lex est regula et mensura actuum, et dicitur a ligando quia obligat. Lex clarum est quod est in natura rationali; et non potest esse nisi in sensu vel in intellectu. Non est in sensu. Ergo..." VITORIA 2010, 88.

11 VITORIA 2010, 92; VITORIA 2008, 23. 


\section{Claudio Brandão ITHE ROOTS OF HUMAN RIGHTS I ISSN 2675-1038}

this orderliness to common good emanates from the norm's distinctive nature, not from the legislator's will, for when common good ceases to exist, the norm also ceases ${ }^{12}$. Thus, the norm is identified as a mandate of reason promulgated by authority for the common good, with binding power.

\section{THE MEANING OF HUMAN RIGHTS IN THE LATE SPANISH SCHOLASTIC}

The expression Human rights has a lot of different senses. Thus, when we use this expression, there isn't agreement of its meaning. Among many possibilities, the substance of this concept can even express opposing ideas. So, "when we talk about human rights, we often don't know what we're talking about"13.

In fact, when the liberal revolutions at the $18^{\text {th }}$ century used the idea of Human rights, they intended to provoke exclusion. By recognizing persons who do not fulfill the humankind criteria, the liberal revolutions made possible segregations of selected groups. That's why the American revolution in the US has established slavery and the French revolution denied political rights for women. In this sense, freedom wasn't a characteristic of all Men and the Human rights was an attribute uniqueness of the free gentlemen.

Currently, International law can't accept anymore this meaning of exclusion by the Human rights' concept and the proof of it are the many UN conventions regulating the inclusion of all Men.

12 LANGELLA 2010, 36.

13 Translation of: "Wenn wir über Menschenrechte sprechen, wissen wir oft nicht, worüber wir sprechen”. KLEIN 2008, 213. 


\section{Claudio Brandão ITHE ROOTS OF HUMAN RIGHTS I ISSN 2675-1038}

We can appoint the concept of Human rights as a western creation, made by Europa and American cultural tradition ${ }^{14}$. That is the focal theme: the western tradition has many roots in late Spanish scholastics. The integration of the different was an important topic defended by their scholars because, with the great navigations of $16^{\text {th }}$ century, the Spanish had discovered many organized groups of men in a much lower civilizing stage.

Francisco de Vitoria didn't get the focus of his work in speculative topics, like the question if the different has or does not have a soul. Instead of this, be wrote about the rights of these persons with lower standard of civilization. The speculative topic doesn't deserve a theoretical discussion: the different is a Human being and perceptibly has a soul. So, Vitoria turns the point for a concrete case: the dominion. The salamantinence wrote:

"Returning now to our main topic, in order that we may proceed in order, I ask first whether the aborigines in question were true owners in both private and public law before the arrival of the Spaniards; that is, whether they were true owners of private property and possessions and also whether there were among them any who were the true princes and overlords of others?"15

Using both the philosophical concept of rationality and the juridical concept of jus gentium, Vitoria contradicted the imperial political power about the rights of the Americans. The main question gravitated around the right of property (dominium). The obviously intention of the emperor was to take ownership of all wealth of the discovered new world. Accordingly:

14 LOHMANN 2008, 47.

15 VITÓRIA 2016, 105. 


\section{Claudio Brandão ITHE ROOTS OF HUMAN RIGHTS I ISSN 2675-1038}

"It is well known how, from the Bulls of Alexander VI - 1493 -, the Spanish Crown considered itself the sovereign owner of the "discovered and undiscovered lands." The Spanish could afford 'manu milita', certain reprisals and punishments, aimed at curbing rebellions and uprisings by the Indians, as well as issuing ordinances and dispositions of those who feel authentic rulers and legislators, with legitimate authority to impose, and with power enough - physical and political, not less than moral - to demand obedience." ${ }^{\text {16 }}$

Thus, supporting political power intents and based in the medieval thought, the current argument was that: the Americans were not baptized and therefore they do not have natural rights or civil rights. But, against this, Vitória wrote:

"On the opposite side we have the fact that the people in question were in peaceable possession of their goods, both publicly and privately. Therefore, unless the contrary is shown, they must be treated as owners and not be disturbed in their possession unless cause be shown." ${ }^{\prime 17}$

By recognizing a nucleon of rights which emerge from belonging of Mankind, regardless the social condition. civilization standard or personal state, Vitoria opposed this question and created the roots of Humans right's concept. The rational potency ${ }^{18}$ (potentiae rationales) is the substance of that nucleon of rights and, in this panorama, the law also protects the Americans. So, the rational condition isn't determined by the standards of culture or civilization, but in the dignity of human nature. About this last

16 OCAÑA GARCIA 1996, 301.

17 VITÓRIA 2016, 106.

18 VITÓRIA 2016, 107. 


\section{Claudio Brandão ITHE ROOTS OF HUMAN RIGHTS I ISSN 2675-1038}

topic, Vitoria says that the Human being, in his nature, is the image of God $^{19}$, so always has dignity for the resemblance with the divinity.

"Dominion is founded on the image of God. Now man is the image of God by nature, that is, by the rational powers (potentiae rationales)" 20

In Vitoria's works, there were many other arguments about the right of property. However, the idea of inclusion of all Human beings in a system of protection, their recognizing dignity, is based on the rational potency. After Vitoria, many others developed the concept of rationality, but the strong and the courageous work of the Salamanca's leader can't be loathed.

So, the practical thought proposed by humanism viewed through Vitoria's "eyes" constructed the framework of the "euroamerican" current structure of Human rights: the rational potency.

Therefore, Vitoria rejected the emperor ethics. About this, Hernandez wrote:

"In 1539, he believed that the moment had finally arrived in which to present his first relection, De Indis, to the university community. Here he established, first, the rights of the Indians to their freedom, their property, their territories, and their self-governance. In the second part, he firmly denied the legitimacy of the then-reigning justifications for a just conquest of the Indies. While in the final part of his relection Vitoria set forth other grounds that provided the Spanish 


\section{Claudio Brandão ITHE ROOTS OF HUMAN RIGHTS I ISSN 2675-1038}

emperor with just grounds for his American expeditions, his rejection of the reigning ethic certainly disturbed many observers because Vitoria mediated and limited the omipotent authority of the emperor by means of new arguments based on careful and precise definition"

Vitoria's ideas had great impact upon both the German school of Natural law and the German idealistic school ${ }^{22}$. Grotius and Purfendorf, for example, where profoundly influenced by him. Consequently, we can conclude his thought has survived and developed. In fact,

"its doctrine, largely opposed to tradition and practice, no less than to the political and economic interests of Power, was gaining adherents; his figure remained alive, thriving for more than a century, in the spirit of the School of Salamanca (...). A great personality - Hugo Grocio - managed to absorb, digest and patent the fundamental ideas of Vitorian thought as something proper and original. Vitoria was, for two centuries, obscured, overshadowed, forgotten. This stage was undoubtedly necessary to be able to reappear later with all the costumes of a true resurrected man, shining with his own light."23

${ }^{21}$ HERNÁNDEZ 1991, 1037.

${ }^{22}$ Criminal law's scholars, as the International's scholars, recognize the great influence of Vitoria, which has survived thru the German doctrine. About this, Mahold says: "The late Spanish scholastics and its doctrine of natural law, which was later assimilated by Hugo Grotius in the period of the German doctrine of natural law and the German idealism, had a decisive role in systematizing the concept of penalty" ${ }^{22}$. Translation of: "Die Spanische Spätscholastik und Naturrechtslehre, die durch Hugo Grotius an die deutsche Naturrechtslehre und an den deutschen Idealismus weitergegeben wurde, hat bei der Systematierung des Strafbegriffes eine maßgebliche Rolle gespielt". MAIHOLD 2005, 2.

23 OCAÑA GARCIA 1996, 298. 


\section{FINAL NOTE}

When Vitoria rejected the emperor's ethics, he actually proposed, in its turn, new foundations to political power's limitation. Departing from both the right of property and human dignity, the salamatinence has created definitions equivalent to the current human rights concept, characterized for promoting inclusion of all Human beings.

Vitoria recognized the aborigines' lowers civilization standards, notwithstanding he turned against the political power purposes based in an interpretative key, namely the rational potency (potentiae rationales). This interpretative key, as he clearly writes, recognizes the dignity of Mankind and has the juridical effect of limiting the power of the emperor.

In effect, for him, the concept of dignity had a theological support, Man was created as God's image. For this reason, the concept of jus gentium got a new substance, according to the practical knowledge of humanism, its application amidst the conquest nation in America, regardless of any condition, which includes a high important question, namely the faith. In this view, the rational potency which characterize human beings, makes their belonging to the law, viewed like a protection system that legitimates the political power.

Here starts the theoretical relationship between Human rights and legitimacy of power. Further, the development of this relationship will become one of the most important law's questions. The root of this relationship, however, is based on the late Spanish scholastics. 


\section{REFERENCES}

BOHRER, Ashley, "Just wars of accumulation: the Salamanca School, race and colonial capitalism”, Race \& Class, 2017.

BRANDÃO, Cláudio, "Bem Jurídico e Norma Penal: a função da antinormatividade na teoria do crime", Delictae: Revista de estudos interdisciplinares sobre o crime, $\mathrm{n}^{\circ} 4,2018$.

BRANDÃO, Claudio, "Francisco de Vitoria and the dogmatic root of contemporary criminal law", in: Bernd OPPERMANN et al (ed.), International Legal Studies III, Halle an der Saale, 2016, 33-46

CASELLA, Paulo, "Presença de Francisco de Vitória", Revista da Faculdade de Direito da Universidade de São Paulo, 1985.

HERNÁNDEZ, Ramon, "The Internationalization of Francisco de Vitoria and Domingo de Soto", Fordham International Law Journal, New York, 1991.

KLEIN, Eckart, "Elf Bemerkungen zur Universalität der Menschenrechte", in: Günter NOOKE et al (ed.), Gelten Menschenrechte universal? Begründungen und Infragestellungen, Freiburg, 2008, 213-17.

LANGELLA, Simona, "Estudio introductorio", in: VITORIA, Francisco de, De legibus, Salamanca, 2010.

LOHMANN, Georg. "Zur Verständigung über die Universalität der Menschenrechte: Eine Einführung " in: Günter NOOKE et al (ed.), Gelten Menschenrechte universal? Begründungen und Infragestellungen, Freiburg, 2008, 47-60.

MAIHOLD, Harald, Strafe für fremde Schuld?, Köln, 2005. 
MEDER, Stephan, Rechtsgeschichte: eine Einführung, Köln, 2008.

OCAÑA GARCIA, Marcelino, "Francisco de Vitória: vida, muerte y ressurección”, Anales del seminario de historia de la filosofia, Madrid, 1996.

VILLEY, Michel, A Formação do pensamento jurídico moderno, São Paulo, 2009.

VITORIA, Francisco de, De legibus, Salamanca, 2010.

VITORIA, Francisco de, De Potestate Civili, Madrid, 2008.

VITÓRIA, Francisco de, Relectiones sobre os indios e sobre o poder civil, Brasília, 2016.

WINROTH, Anders, The making of Gratian's Decretum, Cambridge, 2000. 